\title{
Increased Soluble Phosphorus Loads to Lake Erie: Unintended Consequences of Conservation Practices?
}

\author{
Helen P. Jarvie, * Laura T. Johnson, Andrew N. Sharpley, Douglas R. Smith, David B. Baker, Tom W. Bruulsema, \\ and Remegio Confesor
}

\begin{abstract}
Cumulative daily load time series show that the early 2000s marked a step-change increase in riverine soluble reactive phosphorus (SRP) loads entering the Western Lake Erie Basin from three major tributaries: the Maumee, Sandusky, and Raisin Rivers. These elevated SRP loads have been sustained over the last 12 yr. Empirical regression models were used to estimate the contributions from (i) increased runoff from changing weather and precipitation patterns and (ii) increased SRP delivery (the combined effects of increased source availability and/or increased transport efficiency of labile phosphorus [P] fractions). Approximately $65 \%$ of the SRP load increase after 2002 was attributable to increased SRP delivery, with higher runoff volumes accounting for the remaining 35\%. Increased SRP delivery occurred concomitantly with declining watershed $P$ budgets. However, within these watersheds, there have been long-term, largescale changes in land management: reduced tillage to minimize erosion and particulate $P$ loss, and increased tile drainage to improve field operations and profitability. These practices can inadvertently increase labile $P$ fractions at the soil surface and transmission of soluble P via subsurface drainage. Our findings suggest that changes in agricultural practices, including some conservation practices designed to reduce erosion and particulate $\mathrm{P}$ transport, may have had unintended, cumulative, and converging impacts contributing to the increased SRP loads, reaching a critical threshold around 2002.
\end{abstract}

\section{Core Ideas}

- A step-change increase in river SRP loads to Lake Erie occurred in the early 2000 s.

- 35\% of the increased SRP loads was attributed to higher runoff volumes.

- $~ 65 \%$ was from increased SRP delivery (source availability and transport efficiency).

- Watershed P stores declined, but conservation tillage and tile drainage increased.

- Well-intentioned conservation measures may have contributed to increased SRP loads.

Copyright $\odot$ American Society of Agronomy, Crop Science Society of America, and Soil Science Society of America. 5585 Guilford Rd., Madison, WI 53711 USA.

All rights reserved.

J. Environ. Qual. 46:123-132 (2017)

doi:10.2134/jeq2016.07.0248

This is an open access article distributed under the terms of the CC BY-NC-ND

license (http://creativecommons.org/licenses/by-nc-nd/4.0/)

Supplemental material is available online for this article.

Received 3 July 2016.

Accepted 23 Nov. 2016

*Corresponding author (hpj@ceh.ac.uk).
$\mathrm{T}$ HERE is growing evidence that Lake Erie, the shallowest, most southern, and most productive of the Laurentian Great Lakes, has entered a marked phase of re-eutrophication after dramatic improvements in water quality during the 1980s and 1990s (Michalak et al., 2013; Conroy et al., 2014; Johnson et al., 2014; Kane et al., 2014). The increasing magnitude and frequency of harmful and nuisance algal blooms, which are particularly problematic in the shallow Western Lake Erie Basin (WLEB), have been directly linked with increasing riverine inputs of soluble reactive phosphorus (SRP; the most readily-bioavailable $\mathrm{P}$ fraction) in major river tributaries, including the Maumee and Sandusky Rivers (Michalak et al., 2013; Baker et al., 2014a, 2014b; Kane et al., 2014; Scavia et al., 2014). In August 2014, a toxic algal bloom in the WLEB cut off drinking water supplies to 400,000 people (Smith et al., 2015c). In 2014, the Lake Erie Ecosystem Priority was established in response to growing challenges relating to phosphorus $(\mathrm{P})$ enrichment, compounded by climate change, and aquatic invasive species (IJC, 2014); in February 2016, the governments of Canada and the United States announced new P targets to improve Lake Erie water quality, including a $40 \%$ reduction in spring total P (TP) and SRP loads (USEPA, 2016).

Several recent studies have evaluated patterns and trends in flow-weighted mean SRP concentrations in the Maumee and Sandusky Rivers (Daloglu et al., 2012; Sharpley et al., 2012; Baker et al., 2014a; Stow et al., 2015). These studies identified the mid-1990s as a critical time, when flow-weighted mean SRP concentrations reached a minimum and then started to increase. Rising riverine SRP inputs have been attributed to a range of factors, including soil stratification and the buildup of labile P fractions at the soil surface, linked to conversion of land to notill cropping systems, surface broadcasting of fertilizer without incorporation in fall and winter, and changing climate patterns and seasonality (e.g., with increased temperatures in late winter and early spring, there is potential for runoff to occur earlier when soils are still frozen) (Smith et al., 2015c; Stow et al., 2015). However, owing to the confounding influences of large weather-induced variations in nonpoint-source P loads, these

H.P. Jarvie, Centre for Ecology \& Hydrology, Wallingford, OX10 8BB, UK; L.T. Johnson, D.B. Baker, and R. Confesor, National Center for Water Quality Research, Heidelberg Univ., Tiffin, OH 44883; A.N. Sharpley, Crop, Soil and Environmental Sciences, Univ. of Arkansas, AR 72701; D.R. Smith, Grassland, Soil and Water Research Laboratory, USDA-ARS, Temple, TX 76502; T.W. Bruulsema, International Plant Nutrition Institute, Guelph, ON, NG1 1L8, Canada. Assigned to Associate Editor Laura Christianson.

Abbreviations: R-B, Richards-Baker; PP, particulate phosphorus; SRP, soluble reactive phosphorus; SS, suspended sediment; TP, total phosphorus; WLEB, Western Lake Erie Basin. 
studies have, to date, been unable to distinguish the effects of changes in the magnitude and availability of SRP sources from increases in runoff resulting from changing rainfall patterns.

Here, we address this gap in understanding of the role of changing runoff volumes through (i) analysis of high-resolution (daily) cumulative load time series to identify the timing of major changes in SRP loads into the WLEB relative to water fluxes and (ii) empirical regression models to account for the effects of changing river flows on increasing SRP loads. By accounting for the effects of changing runoff volumes on river SRP loads, it was possible to apportion and quantify patterns in increased SRP delivery across the three watersheds. Here, "increased SRP delivery" is defined as the combined effects of increased watershed SRP source availability and increased efficiency of SRP transport to the river, which is linked to structural changes in flow pathways that are in addition to the effects of changing runoff volume per se. The drivers of increased delivery of SRP were then explored in relation to patterns in P source availability (including agricultural $\mathrm{P}$ inputs, cropped land, watershed $\mathrm{P}$ budgets, and tillage practices) and hydrological pathways and connectivity.

\section{Materials and Methods}

Long-term water quality time series data were analyzed for three major agricultural watersheds draining into the WLEB: the Maumee $\left(16,338 \mathrm{~km}^{2}\right)$, Sandusky $\left(3240 \mathrm{~km}^{2}\right)$, and Raisin Rivers $\left(2700 \mathrm{~km}^{2}\right)$ (Supplemental Fig. S1). A summary of the watershed characteristics are provided in Table 1. Agriculture accounts for $78 \%$ of the Sandusky watershed, $73 \%$ of the Maumee watershed, and $50 \%$ of the Raisin watershed, with corn (Zea mays L.) and soybeans [Glycine $\max$ (L.) Merr.] being the dominant crops. Urban land accounts for $11 \%$ of the watershed area in the Raisin and Maumee and 8\% in the Sandusky.

\section{Measurement of River P and Suspended Sediment Loads}

Regular daily sampling of the Sandusky and Maumee Rivers began in 1974 and in 1982 for the Raisin River. Water quality samples were collected in close proximity to USGS stream gauging stations at the watershed outlets (Supplemental Fig.
S1). Automatic water samples collected three to four river water samples per day, which were analyzed for a range of determinands, including SRP, TP, and suspended sediment (SS) concentrations (see Supplemental Methods). Here, particulate P (PP) is calculated as the difference between TP and SRP concentrations. Daily flow data were obtained from the National Water Information System of the USGS. Daily loads were derived by multiplying the flow-weighted mean concentration for each day by the average discharge for that day (Baker et al., 2014a).

\section{Analysis of High-Resolution (Daily) Cumulative Load Time Series}

Cumulative daily loads were calculated from the daily river SRP, PP, and SS load datasets, normalized to watershed area, and plotted as time series (Fig. 1, Supplemental Fig. S2). Two major changes in cumulative SRP load gradients were observed across

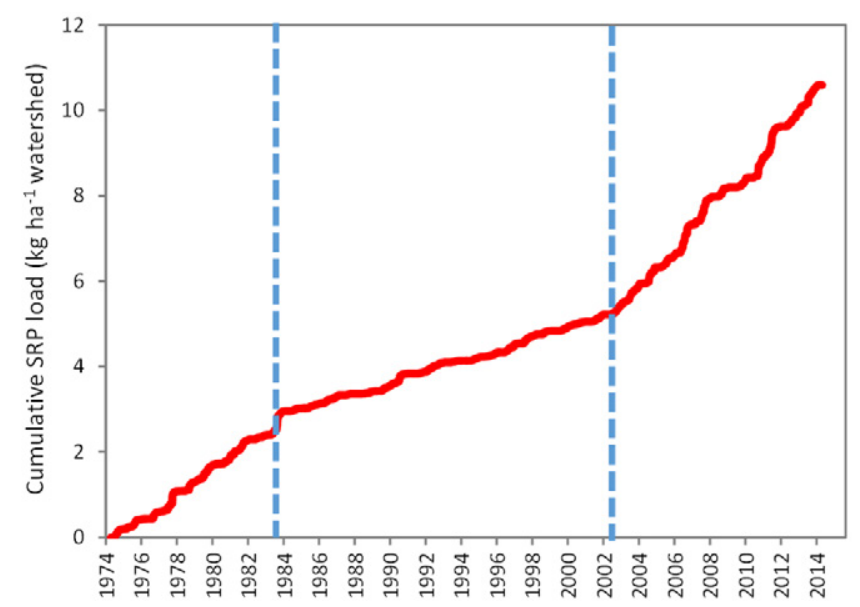

Fig. 1. An example cumulative load time series for soluble reactive phosphorus (SRP) in the Sandusky River (1974 to 2014). The blue broken lines denote major changes in gradient of SRP load accumulation. Please see Supplemental Fig. S2 and Table 2 for comparison of gradients in the cumulative load time series for the Sandusky, Maumee, and Raisin Rivers for SRP, particulate $P$ and suspended sediment loads, and water flux.

Table 1. Summary of the watershed characteristics for the Sandusky, Raisin, and Maumee Rivers. Watershed land use data were derived from the 2006 National Land Cover database (http://www.mrlc.gov/nlcd2006.php). Watershed soil drainage characteristics and estimates of agricultural land underlain by tile drains were derived from the SSURGO database (http://websoilsurvey.nrcs.usda.gov/). The estimates of percentage agricultural land in high-residue management (no tillage and strip tillage) were derived from residue management surveys from the National Resource Inventory (NRI). The R-B flashiness index is the Richards-Baker flashiness index (Baker et al., 2004). For further information on how land use and soil drainage characteristics, residue management, and the R-B index were calculated, see the Supplemental Methods.

\begin{tabular}{|c|c|c|c|}
\hline Characteristic & Sandusky & Raisin & Maumee \\
\hline Watershed area $\left(\mathrm{km}^{2}\right)$ & 3,240 & 2,700 & 16,338 \\
\hline Agriculture (\%) & 78 & 50 & 73 \\
\hline Agricultural land in corn (\%) & 35 & 34 & 35 \\
\hline Agricultural land in soybeans (\%) & 52 & 38 & 51 \\
\hline Agricultural land in wheat (\%) & 8 & 9 & 8 \\
\hline Forest (\%) & 9 & 11 & 6 \\
\hline Grassland (\%) & 4 & 19 & 6 \\
\hline Urban (\%) & 8 & 11 & 11 \\
\hline Wetland (\%) & 0.3 & 8 & 2 \\
\hline Total (and rural) population density in 2010 (people km²) & $68(27)$ & $86(31)$ & $68(22)$ \\
\hline Estimate of agricultural soils classed as well drained (\%) & 17 & 35 & 18 \\
\hline Estimate of agricultural land underlain by tile drains (\%) & 92 & 62 & 86 \\
\hline $\begin{array}{l}\text { Estimate of agricultural land in high-residue management practices } \\
\text { (includes conservation tillage) based on } 2012 \mathrm{NRI} \text { survey (\%) }\end{array}$ & 64 & 58 & 71 \\
\hline Mean R-B flashiness index (1984 to 2014) & 0.375 & 0.160 & 0.272 \\
\hline
\end{tabular}


all three watersheds: first, a decrease in gradient around the mid1980 s, and second, a marked increase in gradient starting in the early 2000s. To establish common "reference points" for comparing changing cumulative load gradients across all three watersheds, sensitivity analyses were undertaken (Supplemental Tables S1a and S1b). First, a sensitivity analysis was undertaken to quantify the effects on cumulative SRP load gradients of varying the reference point from 2000 to 2004 (Supplemental Table S1a). From this, 2002 was chosen as the common reference point. A second reference point of 1984 was derived using sensitivity analysis for the earlier reductions in SRP loads (Supplemental Table S1b).

Cumulative load gradients of SRP, PP, and SS and percentage changes in these cumulative load gradients were then calculated for three periods: (i) up to 1984 (which corresponds with the period from 1974 to 1984 for the Sandusky and Maumee and 1982 to 1984 for the Raisin), (ii) 1985 to 2002, and (iii) 2003 to 2014 (Table 2). The cumulative load gradients also provide a measure of the mean annual SRP, PP, and SS loads (in $\mathrm{kg} \mathrm{P}$ $\mathrm{ha}^{-1} \mathrm{yr}^{-1}$ and $\mathrm{kg} \mathrm{SS} \mathrm{ha-1} \mathrm{yr}^{-1}$ ). As changing river flows provide a major control on $\mathrm{P}$ and suspended-sediment loads, the changes in cumulative load gradients were compared with corresponding changes in cumulative river flow (water flux) gradients.

\section{Estimating Changes in SRP Delivery}

Empirical models based on regression relationships between SRP concentration and flow were used to apportion and separate the effects of increased runoff from increased SRP delivery arising from greater SRP source availability and/or transport efficiency. For each river, linear regression models were derived for the SRP concentration-flow relationships for data collected between (i) 1985 and 2002 and (ii) 2003 and 2014 (Supplemental Table $\mathrm{S} 2): y=m x+c$, where $y$ is the SRP concentration in $\mathrm{mg} \mathrm{L}^{-1}, x$ is the flow in $\mathrm{Mm}^{3} \mathrm{~d}^{-1} ; m$ is the slope, and $c$ is the intercept. The predicted SRP concentrations from the linear regression models were then multiplied by the corresponding daily river flow to produce modeled daily SRP loads, which were then aggregated to modeled (predicted) annual SRP loads and compared with the observed (measured) annual SRP loads (Supplemental Table S3). To account for the effects of increased runoff on increased SRP loads after 2002, the 1985 to 2002 empirical models were then applied to the 2003 to 2014 flow datasets for each river. The difference between the measured mean annual SRP loads for 2003 to 2014 and the predicted mean annual SRP loads for 2003 to 2014 (using the 1985 to 2002 regression model) provides an estimate of the increase in mean annual river SRP loads, which could be attributed to increased SRP delivery after 2002.

\section{Watershed P Balances}

Cropland and watershed-level P input and P balance data were obtained from the NuGIS database (IPNI, 2012) (Supplemental Tables S4 and S5). Phosphorus inputs and outputs for the three WLEB watersheds were aggregated at the watershed scale (Supplemental Table S5) and compared with river TP and SRP loads. Annual partial watershed P balances were calculated as the difference between $\mathrm{P}$ inputs (from fertilizer and manure) and $\mathrm{P}$ losses (from crop harvest and river export). The human P loading (from wastewater treatment plants and septic tanks) to these watersheds is estimated to contribute $<5 \%$ of the agricultural $\mathrm{P}$ inputs (Supplemental Table S5), and the rural population in all three watersheds declined between 1980 and 2010 (Supplemental Fig. S3a). Nonpoint P export from nonagricultural areas and geological and sedimentary weathering sources are also assumed to contribute a small background but relatively constant percentage contribution to total inputs in these watersheds (Baker and Richards, 2002). Neither of these minor sources would explain the observed trend in riverine SRP and so are not analyzed further here. The estimated watershed $\mathrm{P}$ balance is, therefore, a watershed partial P balance; however, its use here is to compare the agricultural component of the $\mathrm{P}$ balance with the riverine $\mathrm{P}$ exports.

\section{Tillage Practices}

Assessment of watershed-wide historical trends in tillage practice across the wider WLEB have, in the past, been hampered by lack of regular tillage transect data and fragmented datasets, which are only available for a subset of counties. Here, we use newly available datasets of relative residue management from 1982 to 2012, which have been developed by the USDA-NRCS as a surrogate for tillage practice data at the watershed scale (USDA-NRCS, 2015) (Supplemental Table S6). Relative residue management is based on the National Resource Inventory (NRI) estimates for the cover and management factor $(C)$ used to calculate the Universal Soil Loss Equation (USLE; USDA-NRCS, 2013, 2015). Residue

Table 2. Gradients for the cumulative load time series of soluble reactive phosphorus (SRP), particulate P (PP), suspended sediment (SS), and river flow. The cumulative load gradients were calculated from $y=m x+c$, where $y$ is the cumulative daily load in $\mathrm{kg} \mathrm{P}^{-1}, x$ is decimal year, $m$ is the cumulative load gradient (in $\mathrm{kg} \mathrm{P} \mathrm{ha}^{-1} \mathrm{yr}^{-1}$ ), and $\mathrm{c}$ is the intercept. Cumulative load gradients were calculated for three time periods, which correspond with the two major shifts in SRP load gradients in 1984 and 2002 (see Fig. 1, Supplemental Fig. S2, and text). Values in parentheses denote the percentage change in cumulative load gradients relative to the immediately preceding time period.

\begin{tabular}{|c|c|c|c|c|c|}
\hline Location & Years & SRP & PP & SS & Flow \\
\hline & & 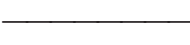 & $-\mathrm{kg} \mathrm{ha}^{-1} \mathrm{yr}^{-1}$ & +2 & $\mathrm{ML} \mathrm{ha-1} \mathrm{yr}^{-1}$ \\
\hline \multirow[t]{3}{*}{ Sandusky } & 1974 to 1984 & 0.298 & 1.39 & 944 & 3.48 \\
\hline & 1985 to 2002 & $0.129(-57 \%)$ & $1.17(-16 \%)$ & $666(-29 \%)$ & $3.08(-12 \%)$ \\
\hline & 2003 to 2014 & $0.456(+253 \%)$ & $1.53(+30 \%)$ & 829 (+25\%) & $4.52(+47 \%)$ \\
\hline \multirow[t]{3}{*}{ Raisin } & 1982 to 1984 & 0.132 & 0.56 & 220 & 3.04 \\
\hline & 1985 to 2002 & $0.066(-50 \%)$ & $0.39(-31 \%)$ & $184(-16 \%)$ & $2.69(-11 \%)$ \\
\hline & 2003 to 2014 & $0.128(+94 \%)$ & $0.39(0 \%)$ & $169(-8 \%)$ & $3.17(+18 \%)$ \\
\hline \multirow[t]{3}{*}{ Maumee } & 1974 to 1984 & 0.342 & 1.47 & 747 & 3.18 \\
\hline & 1985 to 2002 & $0.168(-51 \%)$ & $1.05(-29 \%)$ & $624(-16 \%)$ & $3.01(-5 \%)$ \\
\hline & 2003 to 2014 & $0.363(+116 \%)$ & $1.18(+12 \%)$ & $608(-3 \%)$ & $3.70(+23 \%)$ \\
\hline
\end{tabular}


management is a combination of tillage intensity, the crop rotation, and the residues left by each crop (see Supplemental Methods). Briefly, the low-residue management corresponds with conventional tillage (physical mixing of the surface soil horizons such as, but not limited to, moldboard and chisel plowing), while high-residue management includes both no tillage and strip tillage. The advantages of these datasets include the watershed-wide coverage and historical records collected every $5 \mathrm{yr}$, which span the entire period of interest, from the early 1980s. The "high-residue management" includes both tillage and residue cover components. While we recognize that the high-residue management likely overestimates no tillage + strip tillage, it also reflects additional residue inputs, as surface residue returned to the soil by the crop is reflected by crop yield, which has also increased over this period (as reflected by "annual P removed in crop harvest" in Supplemental Table S4).

\section{Watershed Drainage Characteristics}

Baseline watershed drainage characteristics were calculated using land use and land cover (LU/LC) and soil (SSURGO) datasets (see Supplemental Methods). The Raisin has a higher percentage of well-drained agricultural soils (35\%), compared with 18 and $17 \%$ in the in the Maumee and Sandusky, respectively (Table 1). The more freely-drained soils in the Raisin are reflected by the estimated lower extent of tile drainage (62\%, compared with 86 and $92 \%$ in the Maumee and Sandusky, respectively). Unfortunately, tile drainage is not routinely captured by agricultural surveys. Therefore, to explore long-term changes in drainage characteristics and flow pathways, we used the Richards-Baker stream flashiness index ( $\mathrm{R}-\mathrm{B}$ index) as a potential surrogate for tile drainage (Baker et al., 2004; see Supplemental Methods, Supplemental Table S7, and Supplemental Fig. S4). Stream flashiness provides a measure of the extent of changes in stream flow over a given time period relative to total discharge during that period (Baker et al., 2004). Increases in $\mathrm{R}-\mathrm{B}$ index can result from increases in land drainage, soil compaction, and rainfall intensity, as well as from an increase in the proportion of water being delivered via quick-flow nearsurface or artificial drainage pathways. Our assumption here is that the installation of tile drainage would tend to increase $\mathrm{R}-\mathrm{B}$ flashiness by providing preferential quick-flow pathways for rapid transmission of water to the river network (Wiskow and van der Ploeg, 2003; Sloan et al., 2016). Clearly, this may be a gross simplification, and the actual hydrological response will be dependent on a multitude of interacting and site-specific factors, including local baseline soil drainage conditions, antecedent moisture conditions, and differences in crop type and soil carbon content (Robinson and Rycroft, 1999; King et al., 2014).

\section{Results}

\section{Cumulative Daily P, Suspended Sediment Load, and Water Flux Time Series}

The daily cumulative SRP load time series in all three rivers revealed consistent shifts: first, a decrease in cumulative SRP load gradient in the mid-1980s, and second, a marked increase in gradient starting in the early 2000s (Fig. 1, Supplemental Fig. S2).

The increase in SRP loads in the early 2000s is of key interest here, linked to the re-eutrophication of Lake Erie. Given the contrasts between the Sandusky, Raisin, and Maumee watersheds in size, hydrology, soils, and land use, the timing of this shift to increased
SRP loads was remarkably synchronous across all three watersheds. To allow direct comparison of changes in cumulative load gradients across all three watersheds, common reference points of 1984 and 2002 were selected from sensitivity analyses (see Materials and Methods and Supplemental Tables S1a and S1b).

Comparing cumulative SRP load gradients between 1985 and 2002 with the earlier period (up to 1984), there were decreases of 57, 51, and 50\% in the Sandusky, Maumee and Raisin basins, respectively (Table 2). The corresponding reductions in cumulative water flux gradient were only 12,5 , and $11 \%$, indicating marked reductions in SRP delivery relative to the reductions in runoff volumes. This likely reflects improvements in wastewater treatment arising from the Clean Water Act of 1972 and the Great Lakes Water Quality Agreement signed in 1972, with updates in 1978 and 1983; the latter update focused on agricultural nonpoint-source controls and led to the eventual increases in conservation tillage (Baker and Richards, 2002; Richards et al., 2009). Decreases in cumulative PP and SS load gradients after 1984 (1985 to 2002) were also greater than the corresponding decreases in cumulative water flux gradients, indicating that reductions in erosion and delivery of particulates were linked to reductions in nonpoint sources of PP and SS. However, these percentage reductions in cumulative PP and SS load gradients were consistently smaller than for SRP, suggesting that the combined effects of point and nonpoint remediation were more effective in reducing losses of labile $\mathrm{P}$ fractions compared with particulate fractions. Indeed, there was very little, if any, implementation of nonpoint controls prior to the 1990s. However, the reductions in nonpoint SRP loadings from the mid-1980s to the late 1990 s coincided with a declining trend in fertilizer application rates and cropland P balance (Bruulsema et al., 2011).

After 2002, the Sandusky exhibited the greatest increase in cumulative SRP load gradient (253\%) relative to the increase in cumulative water flux gradient (47\%); for the Maumee and Raisin, cumulative SRP load gradients increased by 116 and 94\%, respectively, compared with 23 and $18 \%$ for the cumulative water flux (Table 2). Therefore, the rise in SRP loads in the three WLEB tributaries after 2002 were greater than what might be attributed simply to increasing runoff volumes, indicating increases in SRP delivery. After 2002, the changes in cumulative PP and SS load gradients were inconsistent. There were small increases in cumulative PP load gradients in the Sandusky and Maumee (30 and 12\%, respectively) but no change for the Raisin, whereas there was a 25\% increase in cumulative SS load gradient in the Sandusky but decreases of 3 and $8 \%$ for the Maumee and Raisin, respectively. After 2002, even where increased cumulative PP or SS load gradients occurred, they were less than the corresponding increase in cumulative water flux gradient. Therefore, although there was an increase in SRP delivery after 2002, relative to flow, there were continued net reductions in PP and SS delivery after 2002, likely reflecting greater adoption of agricultural conservation practices aimed at reducing erosion and sediment delivery (USDA-NRCS, 2016). This also suggests that processes controlling the increases in SRP loads after 2002 are decoupled from those controlling PP and SS loads.

\section{Accounting for the Increases in Flow after 2002 to Quantify the Increase in Soluble Reactive P Delivery}

The statistics for the linear regression models between SRP concentration and flow are shown in Supplemental Table S2 
(all $>99 \%$ significance). The modeled daily SRP loads for each river (derived from multiplying the predicted daily SRP concentrations by the corresponding daily river flow) were compared with the observed (measured) daily loads (Supplemental Table S3) (all $>99 \%$ significance). Figure 2 shows the measured SRP loads for the Sandusky River plotted against flow, with the corresponding predicted SRP loads.

Table 3 shows the measured mean annual SRP loads for 1985 to 2002 (column a) and 2003 to 2014 (column b). After 2002, mean annual SRP loads increased by $0.062 \mathrm{~kg} \mathrm{P} \mathrm{ha}^{-1} \mathrm{yr}^{-1}$ in the Raisin, $0.195 \mathrm{~kg} \mathrm{P} \mathrm{ha}^{-1} \mathrm{yr}^{-1}$ in the Maumee, and $0.327 \mathrm{~kg}$ $\mathrm{P} \mathrm{ha}^{-1} \mathrm{yr}^{-1}$ in the Sandusky (column c). Applying the 1985 to 2002 SRP concentration versus flow regression relationships to the 2003 to 2014 daily river flow dataset, provides an estimate of river SRP loads for 2003 to 2014 arising from changes in flow alone (column $\mathrm{d}$ ). The difference between the measured mean annual SRP loads for 2003 to 2014 (column b) and the predicted mean annual SRP loads for 2003 to 2014, using the 1985 to 2002 regression model (column d), provides an estimate of the increase in mean annual river SRP loads, which could be attributed to increased SRP delivery after 2002 as a result of increased source availability and/or efficiency of transmission of labile P fractions (column e). The average increases in SRP load, which could be attributed to increased SRP delivery after 2002, were 0.039 (Raisin), 0.129 (Maumee), and $0.211 \mathrm{~kg} \mathrm{P} \mathrm{ha}^{-1} \mathrm{yr}^{-1}$

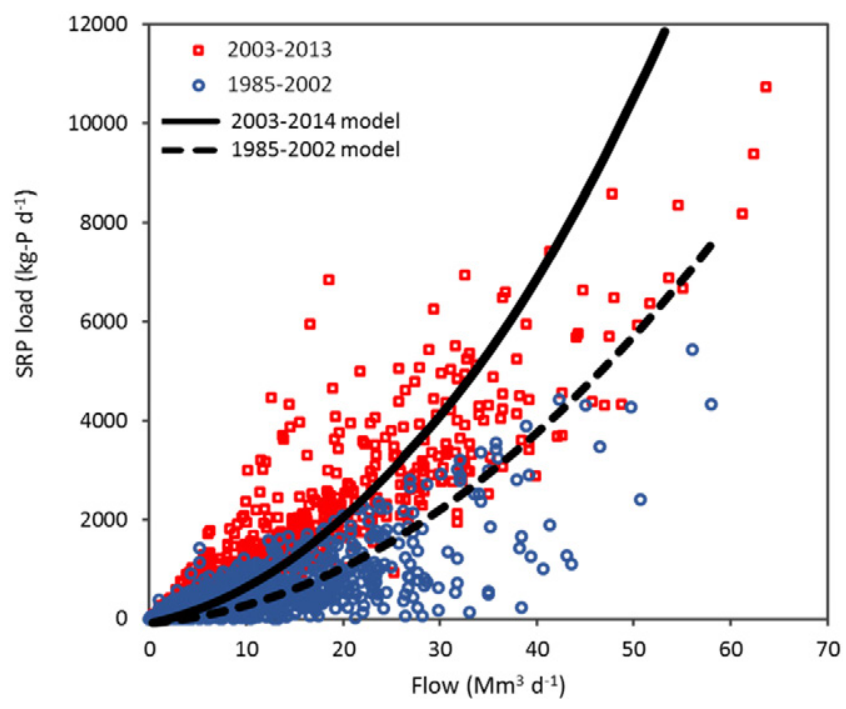

Fig. 2. Soluble reactive phosphorus (SRP) daily loads plotted against flow for the Sandusky River, showing modeled SRP loads for 1985 to 2002 and for 2003 to 2014.
(Sandusky). Consequently, the balance of the post-2002 SRP load increase can be attributed to higher runoff (column $\mathrm{f}$ ). The increase in SRP delivery after 2002 accounted for 63 to $66 \%$ of the increase in mean annual SRP loads for 2003 to 2014 in the Sandusky, Maumee, and Raisin (column g).

\section{Changes in P Source: P Inputs and Budgets for Cropland and at the Watershed Scale}

Annual $P$ applications to cropland (manure and inorganic fertilizer), P removed by crop harvest, and a partial cropland P balance (cropland $\mathrm{P}$ inputs minus $\mathrm{P}$ in harvested crops) are summarized in Supplemental Table S4, comparing two time periods: (i) 1987 to 2002 and (ii) 2007 to 2012. Over this time scale, there were only small increases in mean annual $\mathrm{P}$ applied to cropland in the Sandusky and Maumee watersheds ( 4 and 6\%, respectively), and an $11 \%$ reduction in mean annual $\mathrm{P}$ applied to cropland in the Raisin watershed. During this time, there was also little change $(<10 \%)$ in the mean percentage cropland area, and $>78 \%$ of $\mathrm{P}$ applications were as inorganic fertilizer, with little change in the $\mathrm{P}$ applied from manure linked to livestock farming (Supplemental Fig. S3b). There were also no largescale increases in acres of the main crop types [corn, soybeans, and wheat (Triticum aestivum L.)] during this time (Supplemental Fig. S3a). However, the average annual P removed in harvested crops increased by $25 \%$ in the Sandusky and $18 \%$ in the Raisin and Maumee watersheds. This compensated for the small increases in P applications in the Maumee and Sandusky watersheds and resulted in overall declines in the cropland partial $\mathrm{P}$ balance in all three watersheds (Supplemental Table S4). Similar increases in crop harvest $P$ removal, relative to fertilizer and manure applications, were reported across the wider Great Lakes region (Bruulsema et al., 2011; Han et al., 2012). In all three watersheds, the average annual cropland partial $\mathrm{P}$ balance declined: from 3.13 to $0.23 \mathrm{~kg} \mathrm{P} \mathrm{ha}^{-1} \mathrm{yr}^{-1}$ in the Sandusky, from 0.97 to $-1.38 \mathrm{~kg} \mathrm{P} \mathrm{ha}^{-1}$ $\mathrm{yr}^{-1}$ in the Maumee, and from -0.61 to $-4.74 \mathrm{~kg} \mathrm{Pha}^{-1} \mathrm{yr}^{-1}$ in the Raisin (Supplemental Table S4). Therefore, even before taking into account $\mathrm{P}$ losses in runoff, the croplands in the WLEB watersheds have shifted from net $\mathrm{P}$ accumulation to either net $\mathrm{P}$ drawdown (Maumee and Raisin) or toward a P balance (Sandusky). These changes in cropland $\mathrm{P}$ balance are also consistent with recent studies on long-term $P$ accumulation and drawdown in the Maumee watershed (Haygarth et al., 2014; Powers et al., 2016).

Corresponding changes in watershed partial mass balances are shown in Supplemental Table S5, which takes into account riverine total $\mathrm{P}$ losses at the watershed scale. Figure $3 \mathrm{a}$ shows the cumulative watershed partial $\mathrm{P}$ balance time series for the

Table 3. Comparison of measured and modeled mean annual soluble reactive phosphorus (SRP) loads. The 1985 to 2002 river SRP concentration versus flow regression models were applied to the daily flow data, from 2003 to 2014. The difference between the measured and modeled SRP loads provides an estimate of the increase in SRP delivery after 2002 (see text for details).

\begin{tabular}{|c|c|c|c|c|c|c|c|}
\hline Location & $\begin{array}{l}\text { (a) Measured mean } \\
\text { annual SRP load } \\
\text { (1985 to 2002) }\end{array}$ & $\begin{array}{c}\text { (b) Measured } \\
\text { mean annual } \\
\text { SRP load } \\
\text { (2003 to 2014) }\end{array}$ & $\begin{array}{c}\text { (c) Measured } \\
\text { increase in mean } \\
\text { annual SRP load } \\
\text { after } 2002(b-a)\end{array}$ & $\begin{array}{l}\text { (d) Modeled mean } \\
\text { annual SRP load } \\
\text { (2003 to } 2014), \\
\text { using the } 1985 \text { to } \\
2002 \text { regression } \\
\text { model }\end{array}$ & $\begin{array}{l}\text { (e) Increase in SRP } \\
\text { load attributed } \\
\text { to increased SRP } \\
\text { delivery }(b-d)\end{array}$ & $\begin{array}{l}\text { (f) Increase in SRP } \\
\text { load attributed } \\
\text { to higher runoff } \\
\text { (c-e) }\end{array}$ & $\begin{array}{l}\text { (g) Increase in SRP } \\
\text { delivery, expressed } \\
\text { as a percentage } \\
\text { of the increase in } \\
\text { mean annual SRP } \\
\text { load after } 2002 \\
(100 \times \mathrm{e} / \mathrm{c})\end{array}$ \\
\hline & & & - $\mathrm{kgP}$ & $\mathrm{ha}^{-1} \mathrm{yr}^{-1}$ & 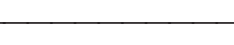 & - & $\%$ \\
\hline Sandusky & 0.129 & 0.456 & 0.327 & 0.245 & 0.211 & 0.116 & 65 \\
\hline Raisin & 0.066 & 0.128 & 0.062 & 0.089 & 0.039 & 0.023 & 63 \\
\hline Maumee & 0.168 & 0.363 & 0.195 & 0.234 & 0.129 & 0.066 & 66 \\
\hline
\end{tabular}



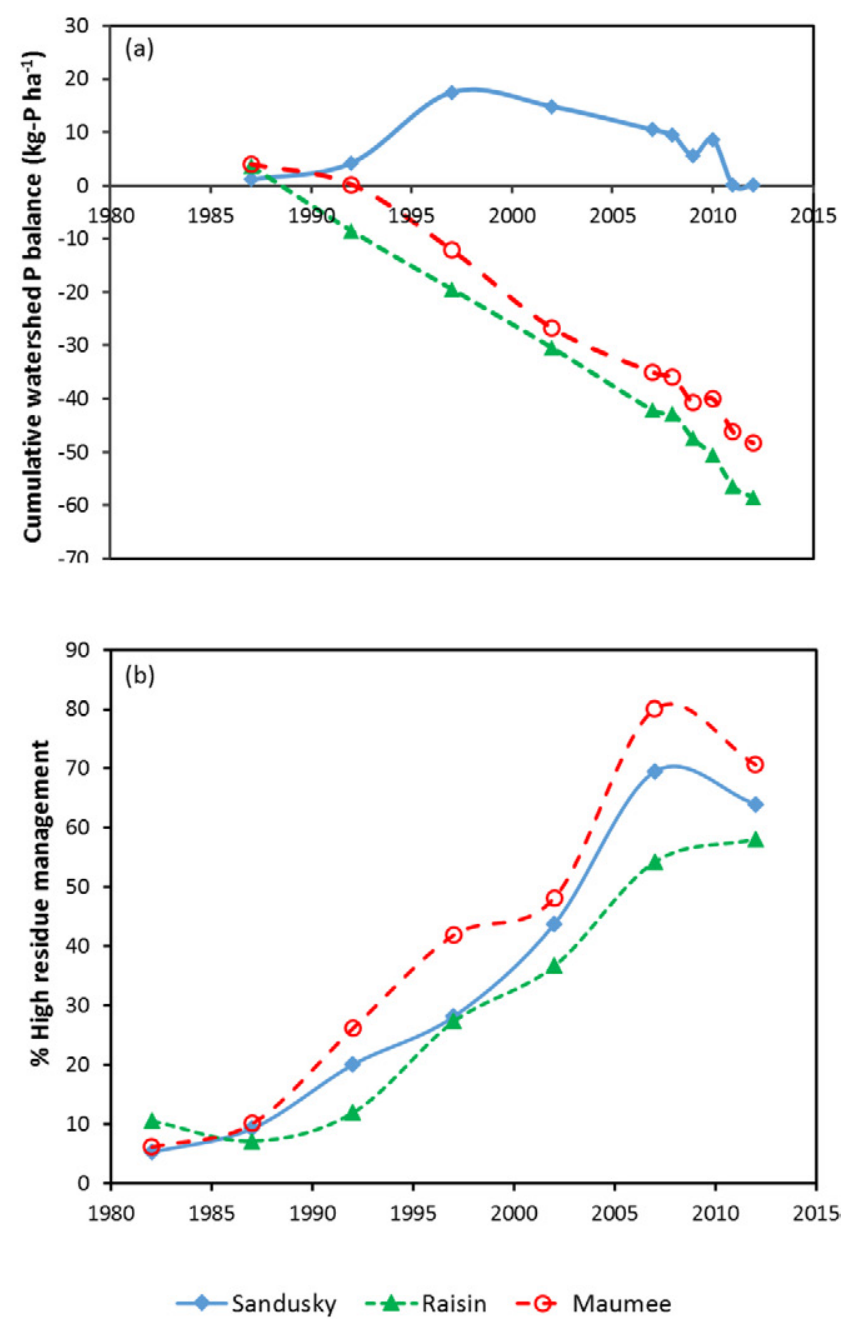

Fig. 3. Time series showing (a) cumulative watershed partial phosphorus (P) balance for the Sandusky, Raisin, and Maumee watersheds (data sources: IPNI and Heidelberg University) and (b) percentage of cropland under high-residue management, which corresponds with some degree of conservation tillage within the rotation (data source: USDA-NRCS). Please see Supplemental Methods and Supplemental Tables S5 and S6 for details.

Sandusky, Raisin, and Maumee Rivers. The Maumee and Raisin showed a net reduction in watershed partial P balance since 1987. In the Sandusky, there was an increase in watershed partial P balance between 1987 and 1997 but a net reduction after 1997. Since 1997, the net P 15-yr drawdowns were $-17,-36$, and $-39 \mathrm{~kg} \mathrm{P}$ $\mathrm{ha}^{-1}$ in the Sandusky, Maumee, and Raisin watersheds, respectively (Fig. 3a). This indicates that the overall size of watershed P stores steadily declined since 1997 . The observed increases in river SRP delivery after 2002 therefore occurred despite these concomitant reductions in watershed P budgets, suggesting changes in watershed function, which may have (i) selectively increased the availability of labile $P$ fractions to be mobilized in runoff relative to PP fractions and/or (ii) increased the hydrological connectivity and the selective transport of the labile $\mathrm{P}$ fractions to the river. This selective increase in the availability and transport of the labile P fractions, relative to PP fractions, is also confirmed by increases in mean river SRP loads, expressed as a percentage of river TP load between 1987 to 2002 and 2007 to 2012: from 13 to $21 \%$ (Sandusky), from 14 to $24 \%$ (Raisin), and from 16 to $23 \%$ (Maumee). Mean river SRP loads, expressed as a percentage of the
$\mathrm{P}$ applied to land, also increased over the same time period, from 1.1 to $3.5 \%$ (Sandusky), from 1 to $1.9 \%$ (Raisin), and from 1.6 to 2.9\% (Maumee) (Supplemental Table S5).

\section{Changes in Land Management and Drainage Characteristics}

Two major factors have been identified among a range of possible contributors to rising SRP loads in the WLEB tributaries (Smith et al., 2015a, 2015b, 2015c): (i) the potential for buildup of labile $\mathrm{P}$ fractions at the soil surface as a result of conversion of land to no-till and minimum-till cropping systems that promote soil stratification, in conjunction with surface broadcasting of fertilizer without incorporation, and (ii) the installation of tile drains, which increase the efficiency of runoff conveyance. Here, we assess long-term changes in watershed-wide tillage practices and tributary drainage characteristics using available datasets covering the period since the early 1980 s. These are presented as a backdrop to observed changes in SRP loads in WLEB tributaries.

Tillage Practices

Across the WLEB watersheds, adoption of the high-residue management level began in the 1980s, and the percentage of cropland under high-residue management rose steadily during the 1990s and early 2000s, reaching a peak in 2007 of $80 \%$ in the Maumee and 70\% in the Sandusky and in 2012 of 58\% in the Raisin (Fig. 3b). The greatest percentage increases in high-residue management occurred between 2002 and 2007, which likely reflect a combination of agricultural policy, higher energy prices (which tend to reduce tillage), and shifts in crop cultivars (the use of herbicide-resistant crops and/or varieties that produce more crop residue). By 2012, 71, 64, and 58\% of cropland land was estimated to be high-residue management in the Maumee, Sandusky, and Raisin watersheds, respectively (Supplemental Table S6).

Although no-till has been widely reported as a major driver of reduced sediment and TP loads to Lake Erie in the late 1980s and 1990s (Richards et al., 2009), no-till also promotes stratification of soil P (Eckert and Johnson, 1985; Duiker and Beegle, 2006; Bullerjahn et al., 2016). Especially where applied P is broadcast for years without incorporation, this can lead to accumulation of highly soluble P fractions at the soil surface (Kleinman et al., 2003; Kleinman and Sharpley, 2003). Stratification of soil available $\mathrm{P}$ occurs in no-till, even when fertilizer is band placed (Duiker and Beegle, 2006; Smith et al., 2016b). No-till also promotes the development of macropores serving as preferential flow pathways for increasing SRP loadings via subsurface drainage (Smith et al., 2015b, 2015c).

\section{Drainage Characteristics}

While there are reports and anecdotal evidence of increasing extent of tile drainage across the WLEB (Ohio Phosphorus Task Force, 2013; Smith et al., 2015b, 2015c), there is a paucity of data on the changing extent of tile drainage. Here, we use trends in stream flashiness as a potential surrogate for changing extent of tile drainage (see Supplemental Methods). The long-term trends in annual R-B flashiness index for the WLEB tributaries (Supplemental Fig. S4, Supplemental Table S7) show increases in hydrological flashiness in the Maumee and Sandusky watersheds since the early 1980s. Over the last $30 \mathrm{yr}$, the greatest increases in R-B flashiness occurred in the Maumee watershed ( 13\%), 
with a smaller increase in the Sandusky watershed ( 6\%). These long-term trends are superimposed on large spatial differences in baseline flashiness within these watersheds, reflecting soil drainage conditions (Table 1). The Raisin watershed had the lowest mean flashiness index (0.160), which is also consistent with well-drained soils: $35 \%$ of the soils in the Raisin watershed were classed as "well drained." In contrast, only $17 \%$ of the soils in the Sandusky and 18\% of the soils in the Maumee watershed are classed as well drained, with the average R-B index of 0.375 and 0.272 , respectively. Roughly $60 \%$ of agricultural land was classed as suitable for tile drainage in the more freely drained soils of the Raisin watershed. This rises to approximately $90 \%$ of agricultural land being suitable for tile drainage in the Sandusky and Maumee watersheds. While there were short-term features and interannual variability in the R-B index time series (including a short-term recent flattening, or decline, in the R-B index), the long-term increase in R-B flashiness in the Maumee and Sandusky watersheds is consistent with anecdotal evidence of increasing tile drainage in these watersheds over the last $30 \mathrm{yr}$ (Ohio Phosphorus Task Force, 2013). Recent studies have also shown that tile drains convey a large proportion of SRP from agricultural fields to streams (King et al., 2014, 2015; Smith et al., 2015b; Williams et al., 2015). In the three WLEB watersheds, the preferential SRP load increases relative to PP and SS loads are also consistent with increased subsurface drainage.

\section{Discussion}

There was a step-change increase in riverine SRP loads to the WLEB in the early 2000s that has been sustained over the last decade. The rise in SRP loads after 2002 was proportionally greater than increases in water flux, indicating that increased runoff is insufficient to account for the observed increase in SRP loads over this period. Moreover, there were no corresponding net increases in PP and SS loads, suggesting that the processes controlling rising SRP loads after 2002 are decoupled from the processes driving PP and SS loads. Since 1997, there were net reductions in the cropland and watershed $P$ balance across all three watersheds.

Empirical regression models suggest that, on average, $~ 65 \%$ of the increase in annual river SRP loads after 2002 could be attributed to increased SRP delivery, reflecting a shift in watershed functioning, with selective increased SRP availability relative to PP fractions and/ or increased SRP transport efficiency. The magnitude of increases in in SRP delivery after 2002 varied spatially, ranging from $0.039 \mathrm{~kg}$ $\mathrm{P} \mathrm{ha}^{-1} \mathrm{yr}^{-1}$ in the Raisin, and $0.129 \mathrm{~kg} \mathrm{P} \mathrm{ha}{ }^{-1} \mathrm{yr}^{-1}$ in the Maumee, to $0.211 \mathrm{~kg} \mathrm{P} \mathrm{ha}^{-1} \mathrm{yr}^{-1}$ in the Sandusky watershed.

The timing of the increase in SRP loads in the early 2000s was synchronous across the three watersheds. Earlier work (Sharpley et al., 2012; Baker et al., 2014a) indicated that annual flow-weighted mean SRP concentrations started to rise in the WLEB watersheds during the mid-1990s. These previously published trends in mean annual flow-weighted SRP concentrations are consistent with SRP loads presented in the current analysis, where the shift to higher SRP loads after 2002 reflects the convergence of rising SRP concentrations combined with higherthan-average flows (Supplemental Fig. S5). Although the annual flow-weighted mean SRP concentrations reached a minimum in 1994 and started to rise thereafter, the greatest year-to-year increase in flow-weighted mean SRP concentrations occurred between 2002 and 2003 (Supplemental Fig. S5). There have also been recent reports of increased streamwater median TP concentrations in pristine (undisturbed) watersheds across the United States of $+2.5 \mu \mathrm{g} \mathrm{P} \mathrm{L}^{-1} \mathrm{yr}^{-1}$ between 2000 and 2014, (Stoddard et al., 2016). However, in the WLEB tributaries, there was no trend of increasing TP concentrations over this time (Supplemental Fig. S5), which likely reflects the overwhelming influence of agricultural land management and conservation practices that override any background trends that may occur in pristine watersheds. Over time, land management changes within the WLEB watersheds have reduced PP delivery but may have unintentionally increased SRP delivery. However, the net effect has been no significant trend in annual flow-weighted TP concentrations over the last 10 to $15 \mathrm{yr}$.

Table 4 summarizes the magnitude of increases in SRP delivery after 2002 in the Sandusky, Raisin, and Maumee watersheds relative to the extent of reduced tillage, river flashiness, and cumulative changes in watershed $\mathrm{P}$ budgets. Across all three watersheds, there have been long-term, largescale increases in the extent of high-residue management (consistent with no-till and reduced tillage), with the greatest percentage increases in the Maumee. The Sandusky and Maumee also showed evidence of long-term increasing hydrological flashiness, which, despite the competing effects of no-till in reducing runoff and flashiness, may be indicative of increasing extent of tile drainage. The greatest increases in SRP delivery after 2002 were in the Sandusky, followed by the Maumee, and the smallest increases were in the Raisin. These increases in SRP delivery correspond with changes in cumulative watershed $\mathrm{P}$ balance and the baseline average $\mathrm{R}-\mathrm{B}$ flashiness. This suggests that watershed susceptibility to increased SRP loss was most closely related to the hydrological connectivity between the land and water (as indicated by the baseline hydrological flashiness) and P source availability. The smaller net drawdown in the watershed P balance in the Sandusky indicates that there may be greater soil $P$ availability remaining.

The increased SRP delivery in all three WLEB watersheds after 2002 indicates a widespread increase in the buildup of labile P pools in locations where they can be readily mobilized and delivered to the drainage network. This is consistent with (i) the gradual buildup of legacy labile $P$ fractions at the soil surface, resulting from widespread adoption of reduced tillage

Table 4. Summary table showing changes in soluble reactive phosphorus (SRP) delivery after 2002, in relation to the increase in the extent of reduced tillage, river flashiness, and cumulative changes in watershed P budgets, for the Sandusky, Maumee, and Raisin watersheds. R-B flashiness index is the Richards-Baker flashiness index (Baker et al, 2004; see Supplemental Methods).

\begin{tabular}{|c|c|c|c|}
\hline & Sandusky & Maumee & Raisin \\
\hline $\begin{array}{l}\text { Increase in river SRP load attributed to } \\
\text { increased SRP delivery }\left(\mathrm{kg} \mathrm{P} \mathrm{ha}^{-1} \mathrm{yr}^{-1}\right)\end{array}$ & 0.211 & 0.129 & 0.039 \\
\hline $\begin{array}{l}\text { Estimate of net 30-yr increase in the } \\
\text { percentage of cropland under high- } \\
\text { residue management between } 1982 \\
\text { and } 2012(\%)\end{array}$ & 64 & 71 & 58 \\
\hline $\begin{array}{l}\text { Mean 30-yr R-B flashiness index } \\
\text { (1984 to 2014) }\end{array}$ & 0.375 & 0.272 & 0.160 \\
\hline $\begin{array}{l}\text { Percentage change in R-B flashiness } \\
\text { index (1984 to 2014) (\%) }\end{array}$ & +6 & +13 & +0.2 \\
\hline $\begin{array}{l}\text { Net change in cumulative } \\
\text { watershed P balance between } 1997 \\
\text { and } 2012\left(\mathrm{~kg} \mathrm{P} \mathrm{ha}^{-1} \mathrm{yr}^{-1}\right)\end{array}$ & -17 & -36 & -39 \\
\hline
\end{tabular}


combined with broadcast fertilizer applications, (ii) the development of preferential flow pathways (i.e., macropores) facilitating direct hydrological connectivity between labile $\mathrm{P}$ at the soil surface and subsurface drainage, and (iii) increasing tile drainage extent, providing direct, rapid, and efficient transmission of surface runoff via soil drainage to the stream network and also increasing the critical source area spatial extent (Sharpley et al., 2011). Land management changes in the WLEB, while extensive, have been gradual and cumulative. They reflect directional shifts to improved conservation practices, with increased levels of reduced tillage, along with installation of tile drainage to increase the efficiency of runoff conveyance and improve field operations and profitability. All of these measures are consistent with recommended conservation practices to reduce TP losses.

As indicated in the introduction, a range of other potential factors could have contributed to the observed increase in river SRP loads to the WLEB in the early 2000s. However, there were no major increases in fertilizer or livestock manure $\mathrm{P}$ application rates during this time, and the rural population actually declined. Anecdotal changes include temporary reductions in winter broadcasting in the 1980s as farmers reduced total P applications. Later, as farm size increased and larger planters without band-fertilizer placement came online, farmers may have again increased the use of broadcast applications. These changes in P fertilizer application methods, which are linked somewhat to conservation tillage practices, could also have contributed, along with soil stratification, to increased availability of labile $\mathrm{P}$ at the soil surface at times of greatest risk of runoff and P loss. Moreover, the use of cover crops, also linked to conservation tillage practices, can bioaccumulate $\mathrm{P}$ at the soil surface if those cover crops are killed and left in the field prior to planting (Miller et al., 1994; Dabney et al., 2001). The age of conservation practices on the landscape may also be significant, as a lack of maintenance can also result in increasing SRP contributions (Osmond et al., 2012; Dodd and Sharpley, 2016). With conservation tillage, there are also fewer opportunities to incorporate broadcast fertilizer into the soil. Data on fertilizer placement are scarce, but as of 2013, just over 50\% of the fertilized cropland area of the Lake Erie watershed in Ohio was applied broadcast without incorporation within $7 \mathrm{~d}$ (LaBarge and Prochaska, 2014). Across the western Lake Erie watershed, comparing 2003 through 2006 with 2012, the percent of cropped acres on which P was incorporated at every application increased from 45 to $60 \%$ (USDANRCS, 2016), indicating that farmers may already be changing practices in response to Lake Erie water quality issues.

The changes in tillage practices, drainage characteristics, and watershed or cropland P budgets were not as sudden as the shift to increased SRP loads after 2002. The step-change increase in SRP delivery likely reflects converging cumulative impacts of gradual changes over the decades before 2002, perhaps culminating in the exceedance of a critical threshold (Jarvie et al., 2015). Rises in SRP loads after 2002 may have also been initiated by higher-than-average flow years (2003-2004) immediately after relatively low-flow years (1999-2002) (Supplemental Fig. S5). Dry antecedent conditions can result in greater $\mathrm{P}$ accumulation and availability at the soil surface, which is readily mobilized by runoff during drought-break conditions (Outram et al., 2016). However, increased SRP load accumulation was sustained over the last $12 \mathrm{yr}$, indicating longer-term structural changes in watershed functioning after 2002, which increased SRP availability and transmission across the WLEB watersheds. Further assessment is now needed to explore whether changing climate patterns linked to seasonal distributions in temperatures, rainfall, and runoff could be contributing to the increased SRP delivery since the early 2000s. However, the increased SRP delivery in the WLEB after 2002, despite steady declines in watershed and cropland $\mathrm{P}$ balances and increased adoption of conservation measures to reduce PP and SS losses, suggests that SRP losses in this watershed are not controlled by these balances and measures and may in fact be increased by some conservation practices.

The spatial extent of conservation-tilled and tile-drained acres may have reached a critical threshold level, increasing the critical source areas of $\mathrm{P}$, as well as conduits for $\mathrm{P}$ loss that bypass a large proportion of the P-sorbing soil matrix (Osmond et al., 2012; Smith et al., 2015b, 2015c). As such, it may be that the shifts in $\mathrm{P}$ balance and $\mathrm{P}$ forms transported from agricultural lands in the WLEB result from the accumulation and interaction of several factors affecting both $\mathrm{P}$ sources and transport (Sharpley et al., 2012; Smith et al., 2015c). This may reflect a "perfect storm" of events transpiring directly and indirectly to overwhelm the reduction in P loss brought about by individual conservation practices (Michalak et al., 2013; Johnson et al., 2014; Jarvie et al., 2015; Stow et al., 2015).

Moreover, these SRP losses represent only a small fraction (average $<5 \%$ ) of the $\mathrm{P}$ applied to land, and the loss is not economically substantial to the grower (Smith et al., 2015c). The new $40 \%$ reduction targets for SRP loads (USEPA, 2016) therefore present technical and economic challenges in decreasing such relatively small but highly bioavailable SRP losses with additional conservation practices, which target these labile fractions (Kleinman et al., 2015; Sharpley et al., 2015). Adoption of the 4Rs of P management (i.e., the right source, rate, timing, and placement of P; IPNI, 2014, Johnston and Bruulsema, 2014) can achieve reductions in SRP delivery through changes to current practices, such as subsurface placement of fertilizer with minimal disturbance of soil residue (Smith et al., 2016a) and occasional tillage to reduce soil stratification (Kleinman et al., 2011, 2015; Sharpley et al., 2015). It is not known, however, how much of the $40 \%$ reduction could be achieved by these $4 \mathrm{R}$ practices alone. Further measures, such as drawing down legacy P sources (Jarvie et al., 2013a, 2013b; Sharpley et al., 2013) and disconnecting tile-flow P loads at times of maximum sensitivity of receiving waters, may be increasingly costly and intrusive to current farm management. Nevertheless, the apparent decoupling of SRP and PP source and transport controls in the WLEB demonstrated in this study strongly suggests that management approaches need to be adapted to tackle both PP and SRP and that additional conservation measures will be needed to address the soluble fraction, which is a relatively small component (average $<25 \%$ ) of the TP load.

\section{Conclusion}

Step-change increases in river SRP loads occurred across the agricultural watersheds of the WLEB in the early 2000s, with the increases in mean annual SRP load ranging from 0.062 and 0.195 to $0.327 \mathrm{~kg} \mathrm{P} \mathrm{ha}^{-1} \mathrm{yr}^{-1}$ in the Raisin, Maumee, and Sandusky, respectively. Around $65 \%$ of these increased SRP loads have arisen from increased SRP delivery (availability and/or transmission of labile $\mathrm{P}$ fractions), with $\sim 35 \%$ from increased drainage water flow. 
Increased SRP delivery occurred despite declining watershed P stores and against a background of long-term changes in land management to reduce soil erosion and PP losses through conservation tillage and improved drainage. Therefore, the increases in SRP delivery likely reflect shifts in watershed functioning: the converging cumulative impacts of gradual selective increases in SRP source availability and increased hydrological connectivity, potentially reaching a threshold of increased SRP delivery in the early 2000s. Well-intentioned conservation measures, while reducing PP losses, may have unintentionally contributed to the rise in ecologically damaging SRP loads entering the WLEB after the early 2000s. Soluble reactive $\mathrm{P}$ losses represent only a small component of the land-applied P (mean $<5 \%)$ and of TP transported by rivers to the WLEB (mean < 25\%), which raises practical, technological, and economic challenges for achieving the new $40 \%$ SRP load reduction targets adopted by the United States and Canada to reduce eutrophication in Lake Erie.

\section{Acknowledgments}

Helen Jarvie acknowledges funding from the UK Natural Environment Research Council (projects NEC04379, Impacts of Nutrient Management, and NEC05966, Strategic Significance of Headwaters). We thank Dr. Alice Robson for assistance with data analysis and statistics; and Ellen Ewing, Barb Merryfield, Jakob Boehler, and Jack Kramer for their diligence in collecting samples over the years.

\section{References}

Baker, D.B., R. Confesor, D.E. Ewing, L.T. Johnson, W. Kramer, and B.J. Merryfield. 2014a. Phosphorus loading to Lake Erie from the Maumee, Sandusky and Cuyahoga rivers: The importance of bioavailability. J. Great Lakes Res. 40:502-517. doi:10.1016/j.jglr.2014.05.001

Baker, D.B., D.E. Ewing, L.T. Johnson, J.W. Kramer, B.J. Merryfield, R.B. Confesor et al. 2014b. Lagrangian analysis of the transport and processing of agricultural runoff in the lower Maumee River and Maumee Bay. J. Great Lakes Res. 40:479-495. doi:10.1016/j.jglr.2014.06.001

Baker, D.B., and R.P. Richards. 2002. Phosphorus budgets and riverine phosphorus export in northwestern Ohio watersheds. J. Environ. Qual. 31:96-108. doi: $10.2134 /$ jeq2002.9600

Baker, D.B., R.P. Richards, T.T. Loftus, and J.W. Kramer. 2004. A new flashiness index: Characteristics and applications to Midwestern rivers and streams. J. Am. Water Resour. Assoc. 40:503-522. doi:10.1111/j.1752-1688.2004. tb01046.x

Bruulsema, T.W., R.W. Mullen, I.P. O'Halloran, and D.D. Warncke. 2011. Agricultural phosphorus balance trends in Ontario, Michigan and Ohio. Can. J. Soil Sci. 91:437-442. doi:10.4141/cjss 10002

Bullerjahn, G.S., R.M. McKay, T.W.Davis, D.B. Baker, G.L. Boyer, L.V.D’Anglada et al. 2016. Global solutions to regional problems: Collecting global expertise to address the problem of harmful cyanobacterial blooms. A Lake Erie case study. Harmful Algae 54:223-238. doi:10.1016/j.hal.2016.01.003

Conroy, J.D., D.D. Kane, R.D. Briland, and D.A. Culver. 2014. Systemic, earlyseason Microcystis blooms in western Lake Erie and two of its major agricultural tributaries (Maumee and Sandusky Rivers). J. Great Lakes Res. 40:518-523. doi:10.1016/j.jglr.2014.04.015

Dabney, S.M., J.A. Delgado, and D.W. Reeves. 2001. Using winter cover crops to improve soil and water quality. Commun. Soil Sci. Plant Anal. 32:12211250. doi: $10.1081 /$ CSS-100104110

Daloglu, I., K.H. Cho, and D. Scavia. 2012. Evaluating causes of trends in longterm dissolved reactive phosphorus loads to Lake Erie. Environ. Sci. Technol. 46:10660-10666. doi:10.1021/es302315d

Dodd, R.J., and A.N. Sharpley. 2016. Conservation practice effectiveness and adoption: Unintended consequences and implications for sustainable phosphorus management. Nutr. Cycling Agroecosyst. 104:373-392. doi:10.1007/s10705-015-9748-8

Duiker, S.W., and D.B. Beegle. 2006. Soil fertility distributions in long-term no-till, chisel/disk and moldboard plow/disk systems. Soil Tillage Res. 88:30-41. doi:10.1016/j.still.2005.04.004

Eckert, D.J., and J.W. Johnson. 1985. Phosphorus fertilization in no-tillage corn production. Agron. J. 77:789-792. doi:10.2134/agronj1985.0002196200 $7700050028 \mathrm{x}$
Han, H., J.D. Allan, and N.S. Bosch. 2012. Historical pattern of phosphorus loading to Lake Erie watersheds. J. Great Lakes Res. 38:289-298. doi:10.1016/j.jglr.2012.03.004

Haygarth, P.M., H.P. Jarvie, S.M. Powers, A.N. Sharpley, J.J. Elser, J. Shen et al. 2014. Sustainable phosphorus management and the need for a long-term perspective: The legacy hypothesis. Environ. Sci. Technol. 48:8417-8419. doi:10.1021/es502852s

IJC. 2014. A balanced diet for Lake Erie: Reducing phosphorus loadings and harmful algal blooms. Report of the Lake Erie ecosystem priority. International Joint Commission. http://www.ijc.org/files/publications/2014\%20 IJC\%20LEEP\%20REPORT.pdf (accessed 6 Dec. 2016).

IPNI. 2012. A nutrient use information system (NuGIS) for the U.S. Norcross, GA, 12 Jan. 2012. International Plant Nutrition Inst., Peachtree Corners, GA. www.ipni.net/nugis (accessed 6 Dec. 2016).

IPNI. 2014. 4R nutrient stewardship portal. International Plant Nutrition Inst., Peachtree Corners, GA. http://www.ipni.net/4R (accessed 6 Dec. 2016).

Jarvie, H.P., A.N. Sharpley, D. Flaten, P.J.A. Kleinman, A. Jenkins, and T. Simmons. 2015. The pivotal role of phosphorus in a resilient water-energy-food security nexus. J. Environ. Qual. 44:1049-1062. doi:10.2134/ jeq2015.01.0030

Jarvie, H.P., A.N. Sharpley, B. Spears, A.R. Buda, L. May, and P.J.A. Kleinman. 2013 a. Water quality remediation faces unprecedented challenges from "legacy phosphorus". Environ. Sci. Technol. 47:8997-8998. doi:10.1021/es403160a

Jarvie, H.P., A.N. Sharpley, P.J.A. Withers, J.T. Scott, B.E. Haggard, and C. Neal. 2013b. Phosphorus mitigation to control river eutrophication: Murky waters, inconvenient truths, and "postnormal" science. J. Environ. Qual. 42:295-304. doi:10.2134/jeq2012.0085

Johnson, L.T., D.B. Baker, R.B. Confesor, K.A. Krieger, and R.P. Richards. 2014. Research to help Lake Erie: Proceedings of the "phosphorus along the land-river-lake continuum" research planning and coordination workshop commentary. J. Great Lakes Res. 40:574-577. doi:10.1016/j. jglr.2014.07.001

Johnston, A.M., and T.W. Bruulsema. 2014. 4R nutrient stewardship for improved nutrient use efficiency. In: M. Amalhay, editor, Proceedings of Symphos 2013: 2nd International Symposium on Innovation and Technology in the Phosphate Industry, Agadir, Morocco. 6-10 May 2013. Elsevier B.V., Amsterdam. p. 365-370.

Kane, D.D., J.D. Conroy, R.P. Richards, D.B. Baker, and D.A. Culver. 2014. Re-eutrophication of Lake Erie: Correlations between tributary nutrient loads and phytoplankton biomass. J. Great Lakes Res. 40:496-501. doi:10.1016/j.jglr.2014.04.004

King, K.W., N.R. Fausey, and M.R. Williams. 2014. Effect of subsurface drainage on streamflow in an agricultural headwater watershed. J. Hydrol. 519:438445. doi:10.1016/j.jhydrol.2014.07.035

King, K.W., M.R. Williams, M.L. Macrae, N.R. Fausey, J. Frankenberger, D.R. Smith et al. 2015. Phosphorus transport in agricultural subsurface drainage: A review. J. Environ. Qual. 44:467-485. doi:10.2134/jeq2014.04.0163

Kleinman, P.J.A., B.A. Needelman, A.N. Sharpley, and R.W. McDowell. 2003. Using soil phosphorus profile data to assess phosphorus leaching potential in manured soils. Soil Sci. Soc. Am. J. 67:215-224. doi:10.2136/sssaj2003.2150

Kleinman, P.J.A., and A.N. Sharpley. 2003. Effect of broadcast manure on runoff phosphorus concentrations over successive rainfall events. J. Environ. Qual. 32:1072-1081. doi:10.2134/jeq2003.1072

Kleinman, P.J.A., A.N. Sharpley, R.W. McDowell, D.N. Flaten, A.R. Buda, L. Tao et al. 2011. Managing agricultural phosphorus for water quality protection: Principles for progress. Plant Soil 349:169-182. doi:10.1007/ s11104-011-0832-9

Kleinman, P.J.A., A.N. Sharpley, P.J.A. Withers, L. Bergstrom, L.T. Johnson, and D.G. Doody. 2015. Implementing agricultural phosphorus science and management to combat eutrophication. Ambio 44: 297-310. doi:10.1007/s13280-015-0631-2

LaBarge, G.A., and S.C. Prochaska. 2014. Soil testing and nutrient application practices of Ohio agronomy retailers. Ohio State Univ. Ext., Marion, OH. http://agcrops.osu.edu/sites/agcrops/files/imce/fertility/Ag\%20Retailer\%20Lake\%20Erie\%20and\%20Ohio\%20River.pdf (accessed 6 Dec. 2016).

Michalak, A.M., E.J. Anderson, D. Beletsky, S. Boland, N.S. Bosch, T.B. Bridgeman et al. 2013. Record-setting algal bloom in Lake Erie caused by agricultural and meteorological trends consistent with expected future conditions. Proc. Natl. Acad. Sci. USA 110:6448-6452. doi:10.1073/pnas.1216006110

Miller, M.H., E.G. Beauchamp, and J.D. Lauzon. 1994. Leaching of nitrogen and phosphorus from the biomass of three cover crop species. J. Environ. Qual. 23:267-272. doi:10.2134/jeq1994.00472425002300020007x

Ohio Phosphorus Task Force. 2013. Ohio Lake Erie phosphorus task force II final report. Ohio Dep. of Agriculture, Ohio Dep. of Natural Resources, Ohio Environmental Protection Agency, and the Lake Erie Commission, Columbus, $\mathrm{OH}$. 
Osmond, D., D. Meals, D. Hoag, M. Arabi, A. Luloff, G. Jennings et al. 2012. Improving conservation practices programming to protect water quality in agricultural watersheds: Lessons learned from the National Institute of Food and Agriculture-Conservation Effects Assessment Project. J. Soil Water Conserv. 67:122A-127A. doi:10.2489/jswc.67.5.122A

Outram, F.N., R.J. Cooper, G. Suennenberg, K.M. Hiscock, and A.A. Lovett. 2016. Antecedent conditions, hydrological connectivity and anthropogenic inputs: Factors affecting nitrate and phosphorus transfers to agricultural headwater streams. Sci. Total Environ. 545-546:184-199. doi:10.1016/j. scitotenv.2015.12.025

Powers, S.M., T.W. Bruulsema, T.P. Burt, N.I. Chan, J.J. Elser, P.M. Haygarth et al. 2016. Long-term accumulation and transport of anthropogenic phosphorus in three river basins. Nat. Geosci. 9:353-356. doi:10.1038/ ngeo2693

Richards, R.P., D.B. Baker, and J.P. Crumrine. 2009. Improved water quality in Ohio tributaries to Lake Erie: A consequence of conservation practices. J. Soil Water Conserv. 64:200-211. doi:10.2489/jswc.64.3.200

Robinson, M., and D.W. Rycroft. 1999. The impact of drainage on streamflow. In: W. Skaggs and J. van Schilfgaarde, editors, Agricultural drainage. ASA, Madison, WI. p. 753-786. doi:10.2134/agronmonogr38.c24

Scavia, D., J.D. Allan, K.K. Arend, S. Bartell, D. Beletsky, N.S. Bosch et al. 2014. Assessing and addressing the re-eutrophication of Lake Erie: Central basin hypoxia. J. Great Lakes Res. 40:226-246. doi:10.1016/j.jglr.2014.02.004

Sharpley, A., H.P. Jarvie, A. Buda, L. May, B. Spears, and P. Kleinman. 2013. Phosphorus legacy: Overcoming the effects of past management practices to mitigate future water quality impairment. J. Environ. Qual. 42:13081326. doi: 10.2134/jeq2013.03.0098

Sharpley, A., P. Richards, S. Herron, and D. Baker. 2012. Case study comparison between litigated and voluntary nutrient management strategies. J. Soil Water Conserv. 67:442-450. doi:10.2489/jswc.67.5.442

Sharpley, A.N., L. Bergstrom, H. Aronsson, M. Bechmann, C.H. Bolster, K. Borling et al. 2015. Future agriculture with minimized phosphorus losses to waters: Research needs and direction. Ambio 44:163-179. doi:10.1007/ s13280-014-0612-x

Sharpley, A.N., P.J.A. Kleinman, D.N. Flaten, and A.R. Buda. 2011. Critical source area management of agricultural phosphorus: Experiences, challenges and opportunities. Water Sci. Technol. 64:945-952. doi:10.2166/ wst.2011.712

Sloan, B.P., N.B. Basu, and R. Mantilla. 2016. Hydrologic impacts of subsurface drainage at the field scale: Climate, landscape and anthropogenic controls. Agric. Water Manage. 165:1-10. doi:10.1016/j.agwat.2015.10.008

Smith, D.R., R.D. Harmel, M. Williams, R. Haney, and K.W. King. 2016a. Managing acute phosphorus loss with fertilizer source and placement: Proof of concept. Agric. Environ. Lett. 1(1):1-4. doi:10.2134/ael2015.12.0015
Smith, D.R., C. Huang, and R. Haney. 2016b. Phosphorus fertilization, soil stratification and potential water quality impacts. J. Soil Water Conserv. (in press).

Smith, D.R., W. Francesconi, S.J. Livingston, and C.H. Huang. 2015a. Phosphorus losses from monitored fields with conservation practices in the Lake Erie basin, USA. Ambio 44:319-331. doi:10.1007/s13280-014-0624-6

Smith, D.R., K.W. King, L. Johnson, W. Francesconi, P. Richards, D. Baker, and A.N. Sharpley. 2015b. Surface runoff and tile drainage transport of phosphorus in the midwestern United States. J. Environ. Qual. 44:495-502. doi:10.2134/jeq2014.04.0176

Smith, D.R., K.W. King, and M.R. Williams. 2015c. What is causing the harmful algal blooms in Lake Erie? J. Soil Water Conserv. 70:27A-29A. doi:10.2489/jswc.70.2.27A

Stoddard, J.L., J. Van Sickle, A.T. Herlihy, J. Brahney, S. Paulsen, D.V. Peck et al. 2016. Continental-scale increase in lake and stream phosphorus: Are oligotrophic systems disappearing in the United States? Environ. Sci. Technol. 50:3409-3415. doi:10.1021/acs.est.5b05950

Stow, C.A., Y. Cha, L.T. Johnson, R. Confesor, and R.P. Richards. 2015. Longterm and seasonal trend decomposition of Maumee River nutrient inputs to western Lake Erie. Environ. Sci. Technol. 49:3392-3400. doi:10.1021/ es 5062648

USEPA. 2016. Governments of Canada and the United States announce phosphorus reduction targets of 40 percent to improve Lake Erie water quality and reduce public health risk. USEPA, Washington, DC. https://www. epa.gov/newsreleases/governments-canada-and-united-states-announcephosphorus-reduction-targets-40-percent (accessed 6 Dec. 2016).

USDA-NRCS. 2016. Effects of conservation practice adoption on cultivated cropland acres in western Lake Erie basin, 2003-06 and 2012. USDANRCS, Washington, DC. http://www.nrcs.usda.gov/Internet/FSE_ DOCUMENTS/nrcseprd889806.pdf (accessed 6 Dec. 2016).

USDA-NRCS. 2015. National resource inventory glossary. USDA-NRCS, Washington, DC. http://www.nrcs.usda.gov/wps/portal/nrcs/detail/ national/technical/nra/nri/processes/?cid=nrcs143_014127 (accessed 6 Dec. 2016).

USDA-NRCS. 2013. 2012 National resources inventory. USDA-NRCS, Washington, DC. http://www.nrcs.usda.gov/Internet/NRCS_RCA/reports/nri_eros_nat.html (accessed 6 Dec. 2016).

Williams, M.R., K.W. King, and N.R. Fausey. 2015. Drainage water management effects on tile discharge and water quality. Agric. Water Manage. 148:43-51. doi:10.1016/j.agwat.2014.09.017

Wiskow, E., and R.R. van der Ploeg. 2003. Calculation of drain spacings for optimal rainstorm flood control. J. Hydrol. 272:163-174. doi:10.1016/ S0022-1694(02)00262-7 